\title{
PENDEKATAN KUANTITATIF SEBAGAI SALAH SATU ALTERNATIF METODE PEMECAHAN MASALAH
}

\author{
Dewi Atika \\ Dosen Tetap Fakultas Ekonomi \\ Universitas Pakuan
}

\begin{abstract}
ABSTRAK
Pemecahan masalah dengan menggunakan pendekatan kuantitatif, semakin banyak dipergunakan baik dikalangan pemerintah maupun kalangan bisnis. Hal ini dikarenakan pemecahan masalah dengan pendekatan kuantitatif diharapkan di satu sisi tujuan dapat tercapai secara optimal dan pada sisi yang lain dengan adanya pemecahan masalah tersebut biaya operasional yang dikeluarkan adalah serendah-rendahnya yaitu dengan mempergunakan sumberdaya yang langka dan mahal secara optimal yang pada akhirnya tujuan dapat dicapai tanpa harus mengeksplorasi seluruh sumberdaya yang ada.
\end{abstract}

Kata kunci: Program Linier, Pendekatan Kuantitatif

\section{Pendahuluan}

Salah satu masalah yang mencolok dalam industri adalah produksi belum dilakukan dengan efisien. Hal ini bisa disebabkan karena penggunaan kapasitas terpasang belum maksimal, dimana pemanfaatan kapasitas terpasang berkaitan erat dengan penggunaan kapasitas mesin.

Inefisiensi dapat pula disebabkan oleh pemakaian dan penyediaan bahan baku yang tidak tepat. Penggunaan kapasitas mesin yang tidak tepat dapat menyebabkan ketersediaan bahan baku yang tidak tepat pula, mungkin mengalami kekurangan bahan baku atau mungkin sebaliknya mengalami kelebihan bahan baku.

Kekurangan bahan baku dapat merugikan perusahaan, sebaliknya kelebihan bahan baku belum tentu menguntungkan perusahaan, selain perlu untuk menyediakan biaya tambahan juga diperlukan ekstra pengawasan mutu yang tidak mudah untuk dilakukan. Dengan keadaan tersebut keuntungan maksimum sulit untuk dicapai.

Untuk menjawab masalah-masalah tersebut diperlukan berbagai alat analisis. Program linier merupakan salah satu alat analisis kuantitatif yang efektif. Keberhasilannya berakar dari keluwesan alat tersebut dalam menjabarkan berbagai situasi kehidupan nyata di bidang-bidang berikut: militer, industri, pertanian, transportasi, ekonomi, kesehatan dan bahkan ilmu social lainnya. Disamping itu tersedianya perangkat lunak komputer yang sangat 
efisien memudahkan pekerjaan dalam pemecahan masalah-masalah program linier yang sangat luas.

Dalam proses produksi suatu industri selalu menggunakan masukan atau sumber daya, untuk menghasilkan tingkat produksi tertentu. Pelaku produksi diharapkan pada pemilihan kombinasi masukan sehingga dicapai aktivitas produksi yang optimal dan menghasilkan keuntungan yang maksimal.

Masalah pengalokasian sumber daya muncul bila terdapat pilihan untuk menentukan tingkat kegiatan dimana masing-masing kegiatan membutuhkan sumber-sumber yang sama sedangkan jumlahnya terbatas. Optimalisasi mengandung pengertian pencapaian suatu keadaan terbaik.

Program linier merupakan salah satu metoda dalam perencanaan terbaik, diantara banyak kemungkinan, banyak alternatif untuk pemecahan masalah dan adanya sumber daya yang terbatas. Program linier adalah suatu cara untuk menyelesaikan persoalan pengalokasian sumber-sumber yang terbatas, diantaranya beberapa aktivitas yang bersaing dengan cara yang terbaik yang mungkin dilakukan atau suatu model umum untuk memecahkan masalah pengalokasian sumber-sumber yang terbatas secara optimal.

Optimalisasi adalah untuk menemukan kombinasi yang optimum (untuk menemukan titik optimum) daripada faktor-faktor yang berhubungan satu sama lain serta dalam jumlah yang sangat besar sekali. Jumlah factor-faktor yang sebesar-besarnya untuk dipakai di dalam perhitungan sesuatu situasi penting sekali, artinya oleh karena semakin banyak faktor yang diperhitungkan akan semakin dekat ke titik ketepatan optimal.

Dalam teknik optimalisasi, fungsi tujuan merupakan unsur yang penting, karena akan sangat membantu menentukan kondisi optimal suatu keadaan. Selain itu pembentukan model perlu perhatian khusus, sebab model akan menjelaskan kompleksitas dan ketidak pastian pengambilan keputusan. Model akan membantu menganalisis dalam mengambil keputusan ke arah kerangka logis secara menyeluruh. Model akan memberikan kerangka logika dan analisa konsisten, dimana model akan memberikan kesempatan untuk mempergunakan secara sistimatis metode kuantitatif yang bermanfaat yang dapat menangani variable-variabel dan interaksi dalam jumlah yang besar.

Suatu proses produksi selalu menggunakan masukan atau sumber daya untuk menghasilkan tingkat produksi tertentu. Pelaku produksi dihadapkan pada pemilihan kombinasi masukan sehingga dicapai aktivitas produksi yang optimal dan menghasilkan keuntungan yang maksimal. 
Prilaku optimasi dapat ditempuh dengan dua cara :

1. Maksimisasi, yaitu dengan menggunakan atau mengalokasikan masukan (biaya) yang sudah tertentu dengan mendapatkan keuntungan yang maksimal (constrained output maximization ).

2. Minimisasi, yaitu untuk menghasilkan suatu tingkat produksi tertentu dengan masukan atau biaya yang paling minimal (constrained cost minimization )

\section{Metode Penelitian}

\section{Metode yang digunakan Program Linier}

Program linier adalah salah satu dari pendekatan matematis yang paling sering dipergunakan dan sukses diterapkan dalam keputusan-keputusan manajerial. Progam linier adalah sebuah alat determenistik, yang berarti bahwa semua parameter model diasumsikan diketahui dengan pasti.Tetapi dalam kehidupan nyata khususnya dunia usaha, jarang ditemukan masalah dimana terdapat kepastian yang sesungguhnya bahkan sebaliknya unsur ketidak pastian yang selalu dihadapi. Untuk mengkompensasikan kekurangan ini program linier memberikan analisis pasca optimum yang statis terhadap perubahan diskrit atau kontinyu dalam berbagai parameter dari model tersebut yang pada akhirnya akan memberikan dimensi dinamis pada sifat pemecahan program linier yang optimal (Taha, 1996).

Program linier adalah suatu cara untuk menyelesaikan persoalan pengalokasian sumber-sumber yang terbatas diantara beberapa aktivitas yang bersaing dengan cara yang terbaik yang mungkin dilakukan (Dimyati dan Achmad, 1992). Persoalan pengalokasian ini akan muncul manakala seseorang harus memilih tingkat aktivitas-aktivitas tertentu yang bersaing dalam hal penggunaan sumber daya langka yang dibutuhkan untuk melaksanakan aktivitas-aktivitas tersebut.

\section{Hasil dan Pembahasan \\ Model Program Linier}

Model matematis perumusan masalah umum pengalokasian sumber daya untuk berbagai kegiatan, disebut model liner programming ( LP ). Pengembangan model matematis dapat dimulai dengan menjawab ketiga pertanyaan berikut ini (Taha, 1996) :

1. Apa yang diusahakan untuk ditentukan oleh model tersebut ? Dengan kata lain apa variable (yang tidak diketahui) dari masalah tersebut? 
2. Apa batasan (kendala) yang harus dikenakan atas variable untuk memenuhi batasan system yang ada di model tersebut?

3. Apa tujuan (sasaran) yang harus dicapai untuk menentukan pemecahan optimal (terbaik) dari semua nilai yang layak dari variable tersebut?

Dalam model LP dikenal 2 ( dua ) macam fungsi, yaitu fungsi tujuan ( objective function ) dan fungsi kendala ( constraint function ).

Fungsi tujuan adalah fungsi yang menggambarkan tujuan atau sasaran didalam masalah LP yang berkaitan dengan pengaturan secara optimal sumber daya-sumber daya, untuk memperoleh keuntungan yang maksimal atai biaya minimal. Sedangkan fungsi kendala merupakan bentuk penyajian secara matematis batasan-batasan kapasitas yang tersedia yang akan dialokasikan secara optimal ke berbagai kegiatan. Secara umum fungsi tujuan dan fungsi kendala dalam program linier dirumuskan dalam tabel standar program linier sebagai berikut : Tabel 1. Tabel Standar Program Linier

\begin{tabular}{|c|c|c|c|c|c|c|}
\hline Sumberdaya & Aktivitas & & & & & Kapasitas sumber \\
\hline & 1 & 2 & 3 & $\ldots$ & $\mathrm{n}$ & \\
\hline 1 & $\begin{array}{ll}\text { a } & 11\end{array}$ & a 12 & a 13 & $\ldots \ldots$ & aln & $>$ b l \\
\hline 2 & a 21 & a 22 & a 23 & $\ldots \ldots$ & $12 n$ & b2 \\
\hline 3 & a 31 & a 32 & a 33 & $\ldots \ldots$ & $13 n$ & b3 \\
\hline$\cdots$ & $\cdots \cdots$ & ...... & $\ldots \ldots$ & ..... & $\ldots \ldots$ & n......... \\
\hline M & A m1 & a $\mathrm{m} 2$ & a $\mathrm{m} 3$ & $\ldots \ldots$ & $\mathrm{amn}$ & bm \\
\hline $\mathrm{Cj}$ & $\mathrm{Cl}$ & $\mathrm{c} 2$ & c3 & $\ldots \ldots$ & $\mathrm{cn}$ & \\
\hline $\mathrm{Xj}$ & $\mathrm{x} 1$ & a 12 & a 13 & $\ldots \ldots$ & $\mathrm{xn}$ & \\
\hline
\end{tabular}

Dalam bentuk matematis model program linier dapat dirumuskan sebagai berikut:

Fungsi tujuan :

Maksimisasi : $\mathrm{Z}=\mathrm{C} 1 \mathrm{X} 1+\mathrm{C} 2 \mathrm{X} 2+$ . $\mathrm{CnXn}$

Fungsi kendala :

$$
\begin{aligned}
& \mathrm{a} 11 \mathrm{x} 1+\mathrm{a} 12 \mathrm{x} 2+\ldots \ldots \ldots \ldots+\mathrm{a} 1 \mathrm{nxn} \leq \mathrm{b} 1 \\
& a 21 \times 1+a 22 \times 2+\ldots \ldots \ldots \ldots+a 2 n \times n \leq b 2 \\
& \mathrm{am} 1 \times 1+a m 2 x 2+\ldots \ldots \ldots+a+a m n x n \leq b m \\
& X j \geq 0, \text { untuk } j+1,2,3 \ldots . n
\end{aligned}
$$

Dimana : 
$\mathrm{Xj}:$ Aktivitas ke $\mathrm{j}$, untuk $\mathrm{j}=1,2,3, \ldots . \mathrm{n}$

$\mathrm{Cj} \quad$ : Koefisien fungsi tujuan, untuk $\mathrm{j}=1,2,3, \ldots \ldots . \mathrm{n}$

Aij : Koefisien tehnis dari kendala, untuk kendala ke-I pada aktivitas ke-j, dimana $I=1,2,3 \ldots . m$ dan $j=1,2,3, \ldots \ldots n$

bi : Sumberdaya yang tersedia atau nilai kendala ke-I untuk $\mathrm{I}=1,2,3, \ldots . \mathrm{m}$

Adapun asumsi yang dipergunakan dalam program linier menurut Nasendi dan Anwar (1985) adalah :

1.

Perbandingan antara input yang satu dengan input yang lain besarnya tetap dan tidak tergantung tingkat produksi (asumsi linieritas).

2. Dampak perubahan peubah pengambil keputusan akan menyebar dalam proporsi yang sama terhadap fungsi tujuan serta kendalanya, dengan kata lain kenaikan output sebanyak dua kali lipat harus diikuti dengan kenaikan input atau sumberdaya sebanyak dua kali lipat juga (asumsi proporsional).

3. Jumlah sumberdaya yang dipakai merupakan jumlah dari sumberdaya yang dipakai oleh berbagai aktivitas baik secara tersendiri maupun bersama (asumsi additivitas).

4. Sumberdaya dan aktivitas dapat dibagi menjadi bilangan pecahan atau non integer (asumsi divisibilitas).

5. Nilai sumua parameter (aktivitas koefisien input-output, harga input dan output serta besarnya kendala) dapat ditentukan dengan pasti dan besarnya tetap, meskipun jarang dapat ditentukan dengan tepat (asumsi deterministik).

6. Variabel-variabel keputusan bersifat non-negatif

Menurut Beneke dan Winterboer (1980) dalam konstruksi model program linier, yang bertindak sebagai peubah tidak bebas adalah pendapatan yang akan dimaksimumkan, sedangkan aktivitas berproduksi dan kendala sumberdaya bertindak sebagai peubah bebas.

Supranto (1980) mengatakan bahwa syarat-syarat yang harus dipenuhi dalam menggunakan program linier adalah :

1. Tujuan yang harus dicapai dapat dinyatakan dalam bentuk fungsi linier yang disebut fungsi tujuan.

2. Harus ada alternatif pemecahan yang membuat nilai fungsi tujuan optimal (maksimal atau minimal) yang harus diperoleh. 
3. Sumberdaya yang tersedia dalam jumlah yang terbatas.

Metode-metode yang digunakan untuk memecahkan model program linier ditujukan untuk mencari solusi dari beberapa alternatif solusi yang dibentuk oleh persamaan-persamaan pembatas, sehingga diperoleh fungsi tujuan yang optimal.

Penyelesaian persoalan dengan program linier dapat menggunakan dua cara yaitu dengan cara grafis dan dengan metode simpleks. Cara grafis digunakan apabila persoalan program linier hanya mempunyai dua variabel saja sedangkan metode simpleks digunakan untuk memecahkan persoalan program linier yang mempunyai variabel keputusan dan pembatas atau kendala yang besar. Dengan metode simpleks, program linier dapat dipecahkan secara bertahap dari sebuah program yang tidak fisibel ke program lain yang fisibel dengan nilai kriteria yang lebih tinggi.

Setiap persoalan program linier selalu memiliki dua macam analisis, yaitu analisis primal dan dual. Keduanya biasa disebut analisis primal dual-dual (Nasendi dan Anwar, 1985). Bila analisis primal bertujuan memaksimumkan pendapatan, maka analisis dual bertujuan meminimumkan biaya, dan sebaliknya.

Tabel 2. Tabel --Primal - Dual Program Linier

\begin{tabular}{|c|c|}
\hline Primal & D u a 1 \\
\hline Maksimum fungsi tujuan & Minimum fungsi tujuan \\
\hline$Z=\operatorname{cjxj}$ & $\mathrm{G}=\mathrm{biYi}$ \\
\hline Dengan syarat : & Dengan syarat \\
\hline Aijxj & $>\quad \mathrm{ci}$ \\
\hline $\mathrm{i}=1,2,3, \ldots \ldots \ldots \mathrm{m}$ & $\mathrm{j}=1,2,3, \ldots \ldots \ldots \mathrm{n}$ \\
\hline $\mathrm{j}=1,2,3, \ldots \ldots \ldots \mathrm{n}$ & $\mathrm{i}=1,2,3, \ldots \ldots \ldots \mathrm{m}$. \\
\hline$x j>0$ & $\mathrm{Yi}>0$ \\
\hline
\end{tabular}

Dimana $\mathrm{Z}=$ cjXj adalah sama dengan $\mathrm{G}=$ biYi dalam kondisi optimal.

Dari sisi ekonomi solusi optimal bentuk dual dapat ditafsirkan sebagai sumbangan per unit sumber daya yang biasa disebut harga bayangan (shadow price). Solusi ini dapat memberikan informasi mengenai kelangkaan sumber daya. Harga bayangan ini menunjukkan besarnya tambahan pendapatan yang diperoleh akibat menambah satu unit lagi sumber daya. Harga bayangan untuk sumber daya langka tidak sama dengan nol. Dengan membandingkan harga bayangan dari setiap sumber daya maka dapat diketahui sumber daya 
yang menjadi kendala utama dalam mencapai kondisi optimal, yaitu sumber daya yang memiliki harga bayangan tertinggi. Sumber daya ini mampu memberikan tambahan pendapatan bersih paling tinggi jika ketersediaannya ditambah satu satuan (Taha, 1996)

Menurut Birowo (1985), beberapa penafsiran yang perlu dipahami pada tahap optimal dari pemecahan masalah dalam program linier adalah :

1. Aktivitas yang masuk dalam program optimal akan memiliki reduced cost atau opportunity cost sama dengan nol. Hal ini menunjukkan bahwa dalam struktur retriksi yang ada, perluasan pengusahaan aktivitas yang masuk dalam proses optimal sebesar satu unit, tidak akan mengubah nilai program optimal.

2. Untuk aktivitas yang tidak masuk dalam program optimal, opportunity cost aktivitas tersebut tidak akan sama dengan nol. Bila satu unit aktivitas ini dimasukkan dalam program optimal akan menurunkan nilai fungsi sebesar opportunitasnya.

3. Pembatas atau restriksi yang terpakai habis akan memiliki harga bayangan (shadow price) yang positif dan tidak sama dengan nol. Penambahan satu unit factor produksi yang terbatas penyediaannya akan menambah nilai program sebesar satu nilai harga bayangan sumberda daya yang terbatas itu. Dalam hal ini harga bayangan mempunyai makna yang serupa dengan nilai marjinal dalam teori produksi.

4. Faktor produksi yang tidak terpakai habis dan masih tersisa, harga bayangannya menjadi sama dengan nol. Penambahan satu unit factor produksi ini dalam program optimal tidak akan mengubah nilai program.

\section{Analisis Kepekaan}

Setiap perubahan nilai koefisien data akan mengubah masalah program linier yang dapat mempengaruhi solusi optimal. Untuk mengembangkan suatu strategi yang dapat memenuhi berbagai ketidak pastian ini maka digunakan analisis kepekaan. Analisis kepekaan adalah suatu cara untuk memperbaiki jawab optimal yang telah dicapai sebagai akibat berfluktuasinya faktor-faktor kendala yang ada tanpa harus memformulasikan kembali masalah tersebut dari awal. Tujuannya adalah mengurangi perhitungan ulang bila terjadi perubahan satu atau beberapa koefisien model pada saat penyelesaian optimal telah tercapai (Subagyo dkk, 1988).

Pada dasarnya perubahan-perubahan yang mungkin terjadi setelah dicapainya penyelesaian optimal terdiri dari perubahan kapasitas sumber daya, perubahan pada koefisien 
fungsi tujuan, perubahan pada koefisien teknis kendala yaitu koefisien yang menunjukkan berapa bagian kegiatan, penambahan variable baru dan penambahan fungsi kendala baru.

Secara umum perubahan-perubahan tersebut akan mengakibatkan :

1. Penyelesaian optimal tidak berubah, artinya baik variable dasar maupun nilai-nilainya tidak mengalami perubahan.

2. Variabel dasar mengalami perubahan, tetapi nilai-nilainya tidak berubah.

3. Penyelesaian optimal sama sekali berubah

\section{Tipe-tipe Khusus Program Linier}

Tipe khusus persoalan program linier adalah Persoalan Transportasi (transportation problem) disamping itu ada juga Persoalan Transshipment dan Persoalan Penugasan (Assignment) yang erat kaitannya dengan persoalan transportasi.

Persoalan transportasi membahas masalah pendistribusian suatu produk dari sumbersumber yang menyediakan produk yang sama, ke tempat-tempat yang membutuhkan secara optimal yaitu dengan tujuan meminimumkan ongkos pengangkutan yang terjadi. Sedangkan persoalan transhipment adalah model transportasi yang memungkinkan dilakukannya pengiriman suatu produk dengan cara tidak langsung, dimana produk atau barang dari suatu sumber dapat berada pada sumber lain atau tujuan lain sebelum mencapai tujuan akhirnya. Persoalan assignment merupakan kasus khusus dari model transportasi, dimana sejumlah "m" sumber ditugaskan kepada sejumlah " $n$ " tujuan (satu sumber untuk satu tujuan) sedemikian rupa sehingga sehingga didapat ongkos total yang minimum.

Adapun ciri-ciri khusus persoalan transportasi menurut Dimyati dan Akhmad (1992) adalah :

1. Terdapat sejumlah sumber (supply) dan sejumlah tujuan (destination, demand) tertentu.

2. Kuantitas komoditi atau barang yang di distribusikan dari setiap sumber dan yang diminta oleh setiap tujuan, besarnya tertentu.

3. Komoditi yang dikirim atau diangkut dari suatu sumber ke suatu tujuan, besarnya sesuai dengan permintaan dan atau kapasitas sumber.

4. Ongkos pengangkutan komoditi dari suatu sumber ke suatu tujuan, besarnya tertentu.

Dalam bentuk matematis model program linier untuk persoalan transportation adalah sebagai beriku : 
Fungsi Tujuan :

$\mathrm{m} n$

Minimumkan $Z=\quad \sum_{i=1 j=1}^{\sum} \mathrm{C}_{\mathrm{ij}} \mathrm{X}_{\mathrm{ij}}$

Dimana :

- Cij adalah ongkos pengiriman per unit komodity dari sumber I ke tujuan j.

- Xij adalah jumlah satuan (unit) yang dikirimkan dari sumber I ke tujuan j.

- bj adalah jumlah kebutuhan masing-masingtujuan.

- ai adalah jumlah kapasitas masing-masing sumber.

Tipe khusus persoalan program linier yang paling penting adalah persoalan transportasi, karena persoalan trasportasi dapat juga digunakan untuk memecahkan masalah-masalah dunia usaha (bisnis), misalnya alokasi dana untuk investasi, analisis lokasi, skejul produksi, dan lain-lain yang kesemuanya terarah pada penyelesaian optimal.

\section{Kesimpulan}

Dari setiap pilihan alternatif pemecahan masalah, hasil yang diharapkan tentunya adalah hasil yang dapat memanfaatkan sumberdaya yang terbatas secara optimal. Dengan menggunakan model matematis, pemecahan masalah dapat terbantu untuk menentukan pilihan yang rasional karena sebuah keputusan dapat diambil dengan memilih alternatif yang dinilai terbaik diantara semua pilihan yang tersedia. Suatu teknik pemecahan masalah dengan menggunakan program linier, dilakukan penyusuana suatu situasi kehidupan nyata ke suatu model matematis yang diarahkan kepada pemecahan masalah dalam satu kesatuan sistem yang dapat menghasilkan suatu nilai optimal dari sistem tersebut sesuai dengan tingkat yang diinginkan, dimana biasanya dalam dunia bisnis diukur dengan biaya dan laba.

\section{Daftar Pustaka}

Dimyati dan Akhmad, 1992. Opertions Research Model-Model Pengambilan Keputusan. Bandung: Sinar Baru.

Frank S. Budnick et all. 1988. Principle of Operations Research for Management.

Nasendi dan Affendi. 1985. Program Linier dan Variasinya. Jakarta: PT Gramedia.

Subagyo dkk. 1991. Dasar-Dasar Operations Research. Yogyakarta: BPFE.

Supranto. 1988. Linier Programming Edisi Kedua. Jakarta: Lembaga Penerbit Universitas Indonesia. 
Taha, H. A. 1987. Operations Reseach an Intoduction. Departement of Industrial Engineering, University of Arkansas, Fayetteville. 